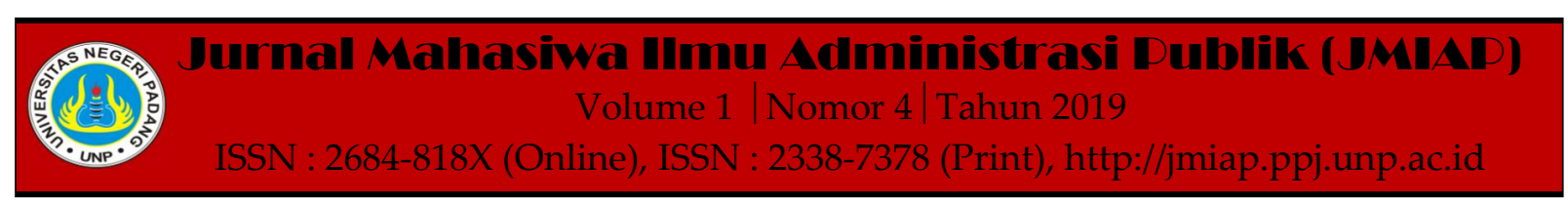

\title{
PENGAWASAN TENAGA KERJA ASING (TKA) OLEH PEMERINTAH PUSAT DAN DAERAH DI KABUPATEN SOLOK SELATAN
}

\author{
Deswinda Eka Putri ${ }^{1(a)}$, Nora Eka Putri ${ }^{2(b)}$ \\ ${ }^{1}$ Jurusan Ilmu Administrasi Negara, Universitas Negeri Padang \\ ${ }^{2}$ Jurusan Ilmu Administrasi Negara, Universitas Negeri Padang \\ a) eka.putri.deswinda@gmail.com, ${ }^{b}$ noraekaputri@fis.unp.ac.id
}

\begin{abstract}
This study aims to examine the supervision of Foreign Workers (TKA) by the Central and Regional Governments in South Solok Regency. This research was conducted at the Department of Manpower and Transmigration, West Sumatra Province, UPTD Labor Inspection Region III West Sumatra Province and the Immigration Office Class I TPI Padang. The method used in this research is to use a qualitative method with a descriptive approach through interview techniques and documentation in data collection. The results showed that the supervision of Foreign Workers (TKA) by the central and regional governments in South Solok Regency had not been running optimally because there were many obstacles that had to be faced by relevant institutions and agencies tasked with overseeing this TKA. Human resources are still lacking, the limited budget provided for supervision activities as well as the lack of facilities and infrastructure needed, especially operational vehicles. This needs to get the attention of the central government so that this monitoring activity can run more optimally.
\end{abstract}

Keywords : Supervision, Foreign Workers (TKA)

Corresponding author. Email. eka.putri.deswinda@gmail.com,noraekaputri@fis.unp.ac.id

How to cite this article. Putri, D. Eka \& Putri, N. Eka. (2019). Pengawasan Tenaga Kerja Asing (TKA) oleh Pemerintah Pusat dan Daerah di Kabupaten Solok Selatan. Jurnal Mahasiwa Ilmu Administrasi Publik (JMIAP) Jurusan Ilmu Administrasi Negara Fakultas Ilmu Sosial Universitas Negeri Padang, Volume 1 (4), Hal. 1-11.

http://jmiap.ppj.unp.ac.id

ISSN : 2684-818X (Online), ISSN : 2338-7378 (Print)

Copyright $(2019$. Published by Pusat Kajian-Pemberdayaan dan Pelayanan Masyarakat (PK-P2M) FIS UNP Padang 


\section{PENDAHULUAN}

Sejak di berlakukannya MEA (Masyarakat Ekonomi ASEAN) pada tahun 2015 yang lalu membuat negara-negara anggota ASEAN bebas untuk melakukan perputaran dan peredaran barang, jasa, modal dan investasi serta takluput didalamnya tenaga kerja. Dengan adanya MEA ini akan membuka jalan lebar bagi para TKA untuk bekerja di Indonesia. Hal ini tentunya tidak dapat dihindarkan bagi Indonesia karena termasuk salah satu anggota dari ASEAN dan pembangunan nasional di dalam negeri juga membutuhkan tenaga-tenaga ahli yang memang berkompeten di bidangnya mengingat ketersediaan para tenaga ahli yang masih kurang di Indonesia. Namun terlepas dari semuanya itu di Indonesia sendiri permasalahan mengenai tenaga kerja ini masih belum teratasi seperti jumlah pengangguran yang masih banyak, pemutusan hubungan kerja dan masih rendahnya kualitas tenaga kerja dalam negeri. Dengan masuknya TKA ini, untuk melakukan pekerjaan di Indonesia maka akan menambah permasalahan baru dan mungkin saja posisi yang harusnya bisa di isi oleh orang indonesia malah di isi oleh orang dari luar negeri.

Keadaan seperti ini perlu dilakukannya persiapan ketenagakerjaan di Indonesia dengan menciptakan tenaga kerja lokal yang kompeten dan terampil agar dapat bersaing dengan TKA yang datang dari berbagai negara ASEAN agar tenaga kerja Indonesia tidak hanya menjadi penonton di negara sendiri, hal ini perlu dilakukan agar pasar kerja di Indonesia tidak di isi oleh TKA yang memiliki kompetensi lebih baik dari tenaga kerja Indonesia. Filosofi atau alasan penggunaan TKA di Indonesia menurut Agusmidah (Suryandono, 2017:11) yaitu asas manfaat berupa perluasan kesempatan kerja, aspek keamanan berupa mekanisme pengendalian TKA termasuk clearance house dan aspek legalitas berupa masuknya TKA harus mendapat izin dari Menteri/working permit.

Tenaga Kerja Asing yang masuk ke Indonesia akan menyebar ke berbagai daerah termasuk di Provinsi Sumatera Barat, daerah ini tidak akan luput dari incaran para TKA yang datang karena di Sumatera Barat juga terdapat beberapa BUMN dan beberapa perusahaan yang bergerak di bidang pertambangan maupun perkebunan. Para TKA yang akan bekerja mesti melengkapi persyaratan dan dinyatakan legal untuk bekerja di perusahaan tujuannya, salah satunya yaitu harus melengkapi IMTA yang dikeluarkan oleh daerah tujuan TKA dimana ia akan bekerja yang di setujui oleh Gubernur sebagaimana yang terdapat dalam (Peraturan Gubernur Provinsi Sumatera Barat Nomor 14 Tahun 2015 tentang Petunjuk Pelaksanaan Retribusi Perpanjangan Izin Mempekerjakan Tenaga Kerja Asing) dijelaskan bahwa IMTA (Izin Mempekerjakan Tenaga Kerja Asing) adalah izin tertulis untuk mempekerjakan tenaga kerja asing yang diberikan oleh Menteri atau pejabat yang ditunjuk kepada pemberi kerja TKA.

TKA yang telah mendapatkan IMTA akan bekerja di daerah kabupaten/kota yang ada di wilayah Provinsi Sumatera Barat termasuk salah satunya di Kabupaten Solok Selatan. Kabupaten ini juga menjadi incaran para TKA karena di daerah ini juga terdapat perusahaan yang bergerak di bidang pertambangan dan perkebunan. Selama lima tahun terakhir dapat diketahui bahwa jumlah TKA yang ada di Sumatera Barat dan Solok Selatan dari tahun 2014-2018 yaitu: 
Deswinda Eka Putri, Nora Eka Putril Pengawasan Tenaga Kerja Asing (TKA) oleh Pemerintah Pusat dan Daerah di Kabupaten Solok Selatan

Tabel 1. Jumlah TKA di Sumatera Barat dan Solok Selatan

\begin{tabular}{cccc}
\hline No & Tahun & Sumatera Barat (orang) & Solok Selatan (orang) \\
\hline 1. & 2014 & 59 & 7 \\
\hline 2. & 2015 & 49 & 4 \\
\hline 3. & 2016 & 47 & 5 \\
\hline 4. & 2017 & 57 & 4 \\
\hline 5. & 2018 & 77 & 4 \\
\hline
\end{tabular}

Sumber: data TKA di Bidang Latihan dan Penempatan Tenaga Kerja Disnakertrans Prov. Sumbar (2019)

Dari data tersebut dapat diketahui bahwa hanya sedikit TKA yang bekerja di Solok Selatan dari tahun 2014 hingga tahun 2018 berdasarkan pada IMTA yang mereka gunakan dan memang mengantongi izin untuk bekerja namun berbeda halnya dengan pemberitaan di media massa seperti yang menyebutkan bahwa banyak TKA di Solok Selatan menyalahi aturan untuk bekerja, diantara beritanya yaitu (Antara Sumbar, September 2016/diakses pada tanggal 7 Februari 2019) Pemerintah kabupaten solok selatan mengirimkan surat pemanggilan kepada Pimpinan PT Bina Bhakti Pratiwi yang membawa TKA ilegal asal Tiongkok dan bekerja sebagai penambang emas, pihak Dinas Sosial Tenaga Kerja dan Transmigrasi telah melayangkan surat pemanggilan kepada PT Bina Bhakti Pratiwi karena sudah dua kali tertangkap mempekerjakan tenaga kerja asing secara ilegal di Solok Selatan dan menyatakan bahwa akan di proses secara hukum.

Kemudian berita yang diterbitkan selanjutnya menyebutkan kasus yang terjadi di tahun 2018 yang lalu yaitu (AntaranewsSumbar, April 2018/diakses pada tanggal 7 Februari 2019) Polres Solok Selatan mengamankan satu orang Warga Negara Asing asal China di lokasi pertambangan emas ilegal karena diduga menyalahgunakan dokumen visa. WNA tersebut Visanya kunjungan keluarga tetapi ia malah masuk kawasan pertambangan emas ilegal dan saat diperiksa paspornya juga tidak ada. Yang menjadi kendala dalam pemerikasaan adalah WNA tersebut tidak bisa berbahasa Indonesia sehingga harus pakai penerjemah, setiap tahun selalu ada WNA asal China yang diamankan polisi dan semuanya di lokasi pertambangan emas.

Dari beberapa berita di atas jelas terlihat bahwa TKA tersebut tidak memiliki izin untuk bekerja di Solok Selatan dan perusahaan yang mempekerjakan mereka juga tidak terdaftar di Dinas Tenaga Kerja dan Transmigrasi Provinsi Sumatera Barat. Hal ini tentunya harus mendapatkan perhatian yang lebih dari pemerintahan daerah Solok Selatan karena mereka bekerja tidak dengan izin yang jelas dan mengambil keuntungan dari potensi yang dimiliki daerah sehingga akan sangat merugikan daerah itu sendiri karena kekayaan alam mereka di ambil dengan percuma oleh TKA ilegal tersebut.

Keberadaan TKA di suatu daerah tidak akan luput dari pengawasan baik TKA yang statusnya legal maupun ilegal yang mana pihak yang melakukan pengawasan TKA adalah Dinas Tenaga Kerja dan Transmigrasi Provinsi Sumatera Barat yang mana dalam melakukan pengawasan ketenagakerjaan di bagi menjadi tiga wilayah kerja yaitu UPTD I di Padang, UPTD II di Payakumbuh dan UPTD III di Sijunjung. Solok Selatan masuk dalam UPTD pengawasan ketenagakerjaan wilayah III di Sijunjung yang mana cakupan wilayah kerja UPTD ini terdapat enam kabupaten/kota yaitu Kota Solok, Kabupaten Solok, Kabupaten Solok Selatan, Kabupaten Dharmasraya, Kabupaten Sijunjung dan Kota Sawahlunto. 
Untuk melihat gambaran awal tentang pengawasan TKA yang di lakukan oleh UPTD III khususnya TKA di Solok Selatan penulis melakukan wawancara dengan Kepala UPTD Pengawasan Ketenagakerjaan Wilayah III Provinsi Sumatera Barat yaitu Bapak Syamsurizal, beliau mengatakan bahwa:

"tugas dari pengawasan mengawasi tenaga kerja yang bekerja di perusahaan. Kalo untuk TKA kita pergi ke perusahaan untuk melihat apakah mereka memiliki IMTA atau tidak. Berkaitan dengan TKA ilegal di Solok Selatan kami pengawas UPTD III sudah sering menangani hal tersebut. yaa kasusnya itu sering di pertambangan emas mereka bekerja tanpa izin. Kita mendapatkan pengaduan dari masyarakat bahwa ada TKA ilegal di daerah mereka dan kami sebagai pengawas langsung turun ke lapangan untuk menindaklanjuti dan memeriksa kelengkapan mereka sebagai orang asing yang bekerja" (hasil wawancara tanggal 2 April 2019).

Dari hasil wawancara tersebut dapat di ketahui bahwa UPTD Pengawasan Ketenagakerjaan Wilayah III Provinsi Sumatera Barat melakukan pengawasan kepada TKA yang bekerja di perusahaan yang ada di Solok Selatan untuk memastikan ada tidaknya izin bekerja baik itu dari IMTA yang dimiliki. Kemudian bagi TKA yang sifatnya ilegal petugas akan segera melakukan pengawasan bila ada laporan dari masyarakat.

Berdasarkan pada permasalahan di atas maka penulis tertarik untuk melakukan penelitian tentang Pengawasan Tenaga Kerja Asing (TKA) oleh Pemerintah Pusat dan Daerah di Kabupaten Solok Selatan”.

\section{TINJAUAN PUSTAKA \\ Konsep Pengawasan}

Menurut (Handoko, 2000:359) pengawasan dapat di defenisikan sebagai proses untuk menjamin bahwa tujuan- tujuan organisasi dan manajemen tercapai, hal ini berkenaan dengan cara-cara membuat kegiatan sesuai dengan yang di rencanakan. Sedangkan menurut (Fahmi, 2016:151) pengawasan merupakan cara yang dilakukan oleh suatu organisasi untuk terciptanya efektif dan efisien dari pelaksanaan kinerja yang dilakukan agar bisa mewujudkan visi dan misi dari organisasi tersebut. Kemudian pendapat lainnya juga di sampaikan oleh Siagian (2011:258) bahwa pengawasan adalah keseluruhan upaya pengamatan pelaksanaan kegiatan opersional guna menjamin bahwa berbagai kegiatan tersebut telah sesuai dengan yang ditetapkan sebelumnya.

Pendapat pakar lainnya seperti Situmorang (Islamiah, Noak, \& Winaya, 2015:3) menyebutkan bahwa pengawasan merupakan seluruh kegiatan yang dilakukan oleh pemerintah tujuanya untuk tercapainya kebijakan atau aturan yang telah ditetapkan. Pengawasan yang dilakukan oleh pemerintah ini adalah salah satu dari fungsi manajemen pemerintah untuk menilai terlaksananya kegiatan yang telah direncanakan.

Adapun tujuan dilakukannya pengawasan dalam organisasi menurut Griffin (Sule dan Kurniawan, 2012:318320) yaitu:

\section{a) Adaptasi Lingkungan}

Hal ini bertujuan agar perusahaan bisa melakukan adaptasi dengan lingkungan disekitarnya dan mampu menghadapi perubahan yang terjadi baik yang datang dari dalam maupun dari luar perusahaan tersebut. Fungsi pengawasan ini tidak hanya untuk memastikan agar tujuan perusahaan dapat berjalan sebagaimana mestinya namun juga berkaitan dengan kegiatan yang sedang dijalankan sesuai dengan perubahan yang akan dihadapi oleh perusahaan yang disebabakan oleh bermacam perubahan dari lingkungan yang ada.

b) Meminimumkan Kegagalan 
Fungsi selanjutnya ialah meminimumkan kegagalan yang mungkin akan terjadi, saat perusahaan melakukan kegiatan produksi maka harapannya agar kegagalan yang akan dihadapi hanya sedikit.

c) Meminimumkan Biaya

Meminimalkan biaya untuk ongkos produksi di dalam perusahaan, fungsi pengawasan disini yaitu melalui penetapan standar dalam kegiatan produksi agar kegagalan yang mungkin akan terjadi dalam produksi akan dapat dihindari.

d) Antisipasi Kompleksitas Organisasi Pada fungsi ini adalah supaya perusahaan bisa menghadapi berbagai macam kegiatan dari organisasi yang begitu banyak dan beragam.

Menurut George R.Terry dan Leslie W.Rue (2012:55) ada beberapa teknik yang dapat di gunakan untuk melakukan pengawasan di antaranya adalah sbb:

a) Pemantauan. Pemantauan di lakukan secara langsung yaitu dengan cara terjun langsung ke lapangan untuk dapat mengetahui kemungkinan terjadinya penyimpangan pelaksanaan suatu kegiatan. Hal ini dapat di lakukan secara berkala maupun sewaktu-waktu apabila di perlukan. Agar pemantauan yang dilaksanakan berjalan dengan tepat maka perlu di lakukan kegiatan menyusun petunjuk pelaksanaan atau petunjuk teknis atau dapat memanfaatkan hasil-hasil pengawasan fungsional maupun pengawasan masyarakat.

b) Pemeriksaan. Pemeriksaan merupakan rangkaian tindakan untuk mencari dan mengumpulkan fakta yang berkaitan dengan faktor-faktor yang mempengaruhi kelancaran pelaksanaan suatu kegiatan. Kegiatan pemeriksaan adalah salah satu bagian dari pengawasan. Pengawasan dapat di lakukan melalui laporan kerja yang di buat oleh pegawai maupun pemimpin yang langsung meninjau kelapangan untuk melihat apakah laporan sesuai dengan kondisi lapangan.

c) Perbaikan. Dalam tahap ini kegiatan yang dilakukan yaitu mencari jalan keluar untuk mengambil langkahlangkah tindakan koreksi terhadap penyimpangan-penyimpangan yang telah terjadi. Tindakan perbaikan ini berguna untuk mengetahui apakah pengawasan yang di lakukan sudah sesuai dengan standar yang di tetapkan sebelumnya.

\section{Konsep Tenaga Kerja Asing (TKA)}

Menurut Undang-Undang Nomor 13 Tahun 2003 Tentang Ketenagakerjaan) Tenaga Kerja Asing adalah warga negara asing pemegang visa dengan maksud bekerja di wilayah Indonesia. Sedangkan menurut Budiono (Suryandono, 2017:69) TKA yaitu setiap orang yang bukan bagian dari warga negara Indonesia atau warga negara asing yang berada di dalam wilayah Indonesia yang mampu untuk melakukan kegiatan pekerjaan guna meghasilkan barang dan jasa untuk pemenuhan kebutuhan masyarakat.

Tenaga Kerja Asing yang datang dan bekerja di Indonesia harus melalui prosedur yang telah ditetapkan melalui kebijakan yang di buat oleh pemerintahan Indonesia. Para pemberi kerja yang menjadi tujuan dari TKA juga harus mengikuti kebijakan ini sebagaimana yang di jelaskan dalam (Peraturan Menteri Ketenagakerjaan Nomor 10 Tahun 2018 tentang Tata Cara Penggunaan Tenaga Kerja Asing) yang mana di jelaskan bahwa Pemberi kerja TKA adalah badan hukum atau badan-badan lainnya yang mempekerjakan TKA dengan membayar upah atau imbalan dalam bentuk lain. Adapun yang menjadi pemberi kerja TKA ini adalah sbb:

1) Instansi pemerintahan, perwakilan negara asing, badan-badan internasional dan organisasi internasional; 
2) Kantor perwakilan dagang asing, kantor perwakilan perusahaan asing dan kantor berita asing yang melakukan kegiatan di Indonesia;

3) Perusahaan swasta asing yang terdaftar di instansi yang berwenang;

4) Badan hukum yang didirikan berdasarkan hukum Indonesia dalam bentuk Perseroan Terbatas atau Yayasan;

5) Lembaga sosial, lembaga keagamaan dan lembaga pendidikan;

6) Usaha Jasa Impresariat;

7) Badan usaha sepanjang tidak dilarang undang-undang.

Setiap pemberi kerja TKA harus mengutamakan penggunaan tenaga kerja Indonesia pada semua jenis jabatan yang disediakan dan dilarang mempekerjakan TKA pada jabatan-jabatan yang tidak boleh di isi oleh TKA atau jabatan yang tertutup bagi TKA. Menurut (Peraturan Menteri Ketenagakerjaan Nomor 10 Tahun 2018 tentang Tata Cara Penggunaan Tenaga Kerja Asing pasal 4) disebutkan bahwa kewajiban yang harus di penuhi oleh setiap pemberi kerja TKA adalah:

a) Memiliki RPTKA yang disahkan oleh Menteri atau pejabat yang ditunjuk;

b) Membayar DKP-TKA untuk setiap TKA yang dipekerjakan sesuai dengan ketentuan peraturan perundang-undangan;

c) Mengikutsertakan TKA dalam program asuransi di perusahaan asuransi berbadan hukum Indonesia yang bekerja kurang dari enam bulan;

d) Mengikutsertakan TKA dalam program Jaminan Sosial Nasional yang bekerja paling singkat enam bulan;

e) Menunjuk Tenaga Kerja Pendamping dalam rangka alih teknologi dan keahlian TKA;

f) Melaksanakan pendidikan dan pelatihan bagi Tenaga Kerja Pendamping; g) Memfasilitasi pendidikan dan pelatihan Bahasa Indonesia kepada TKA yang dipekerjakan.

\section{METODE PENELITIAN}

Dalam penelitian ini, peneliti menggunakan metode Kualitatif dengan pendekatan deskriptif. Penelitian ini dilakukan di Dinas Tenaga Kerja dan Transmigrasi Provinsi Sumatera Barat, UPTD Pengawasan Ketenagakerjaan Wilayah III Provinsi Sumatera Barat, Kantor Imigrasi Kelas I TPI Padang dan Dinas Tenaga Kerja dan Transmigrasi Kabupaten Solok Selatan. Dalam penelitian ini dalam penentuan informan penelitian, peneliti menggunakan teknik Purposive Sampling.

Menurut Sugiyono (2017:218) Purposive Sampling adalah pertimbangan yang dilakukan untuk mengambil sampel dari sumber data. Artinya dalam teknik ini dikatakan bahwa informan yang dipilih adalah mereka yang di anggap paling mengerti tentang apa yang kita inginkan dan harapkan serta akan memudahkan peneliti untuk mendalami objek penelitian yang sedang dijalankan. Dalam penelitian ini akan menggunakan data primer yang merupakan data utama dalam penelitian ini yaitu berupa hasil wawancara dan data sekunder berupa data pendukung atau pelengkap dari data primer. Adapun data yang dikumpulkan di lakukan melalui wawancara dan hasil dokumentasi. Uji keabsahan data dari penelitian ini menggunakan triangulasi sumber artinya data yang telah di kumpulkan akan dipilih dan disajikan sesuai dengan indikator yang peneliti gunakan sehingga di akhir akan dapat di tarik kesimpulan dan jawaban dari penelitian yang di lakukan.

\section{HASIL DAN PEMBAHASAN}

Dalam penelitian ini penulis menggunakan teori pengawasan yang dikemukakan oleh George R.Terry dan Leslie W.Rue (2012:55) bahwa ada beberapa teknik yang dapat di gunakan 
untuk melakukan pengawasan, pengawasan dalam penelitian ini berkaitan dengan pengawasan Tenaga Kerja Asing oleh Pemerintah Pusat dan Daerah di Kabupaten Solok Selatan. Indikator teknik pengawasan tersebut dianalisis berdasarkan pada hasil wawancara yang telah peneliti lakukan dengan informan penelitian. Adapaun teknik pengawasan yang telah di analisa peneliti dapat di uraikan sbb:

\section{Pemantauan}

Pemantauan di lakukan secara langsung yaitu dengan cara terjun langsung ke lapangan untuk dapat mengetahui kemungkinan terjadinya penyimpangan pelaksanaan suatu kegiatan. Hal ini dapat di lakukan secara berkala mapun sewaktuwaktu apabila diperlukan, agar pemantauan yang di laksanakan berjalan dengan tepat maka perlu di lakukan kegiatan menyusun petunjuk pelaksanaan atau petunjuk teknis atau dapat memanfaatkan hasil-hasil pengawasan fungsional maupun pengawasan masyarakat.

Dalam melakukan pemantaun terhadap Tenaga Kerja Asing (TKA) di Kabupaten Solok Selatan telah dilakukan dengan baik dilihat dari pemantaun yang dilakukan oleh Dinas Tenaga Kerja dan Transmigrasi Provinsi Sumatera Barat, UPTD Pengawasan Ketenagakerjaan Wilayah III Provinsi Sumatera Barat dan Kantor Imigrasi Kelas 1 TPI Padang yang mana telah melakukan pengawasan secara langsung ke lapangan dan memiliki jadwal kerja dalam melakukan pengawasan ketenagakerjaan ke perusahaan tempat TKA tersebut bekerja serta dalam melakukan pengawasan tersebut telah menggunakan Juknis yang sesuai dengan aturan yaitu Undang-Undang Ketenagakerjaan Nomor 13 Tahun 2003, Peraturan Presiden Nomor 20 Tahun 2018 dan Peraturan Menteri Ketenagakerjaan Nomor 10 Tahun 2018 tentang Penggunaan Tenaga Kerja Asing yang mana aturan tersebut di jadikan sebagai pedoman oleh petugas pengawas dalam melakukan pengawasan terhadap TKA di Kabupaten Solok Selatan dan belum adanya Peraturan Daerah yang mengatur tentang TKA ini.

Pemantauan ini dilakukan oleh petugas pengawas atau personil intelijen secara langsung ke perusahaan tempat TKA tersebut bekerja yang ada di Kabupaten Solok Selatan, yang mana TKA yang bekerja di perusahaan yang telah terdaftar, mempunyai IMTA dan memiliki izin dari Dinas Tenaga Kerja dan Transmigrasi Provinsi Sumatera Barat yang berwenang untuk memberikan izin kepada TKA ini untuk bekerja di wilayah Provinsi Sumatera Barat. Dan untuk TKA yang kerap menyalahi aturan dan tidak memiliki izin untuk bekerja di Wilayah Solok Selatan akan langsung ditindaklanjuti oleh Dinas Tenaga Kerja dan Transmigrasi Provinsi Sumatera Barat dan dibantu oleh Kantor Imigrasi Kelas I TPI Padang bila memang harus jalan keluar yang ditempuh untuk pelanggaran TKA ini ialah di depotasi untuk kembali ke negaranya. Namun pengawasan untuk TKA yang ilegal ini petugas pengawas kerap menunggu laporan dari masyarakat bila ada TKA di suatu daerah yang tidak mengantongi izin dan melakukan tindakan ataupun kegiatan yang akan merugikan masyarakat maka petugas pengawas akan segera menindaklanjuti laporan masyarakat tersebut dan segera melakukan pemantauan ke lapangan. Dan hal ini telah dilakuakn dengan baik oleh lembaga dan dinas terkait yang berwenang mengawasi TKA di Kabupaten Solok Selatan.

\section{Pemeriksaan}

Pemeriksaan merupakan rangkaian tindakan untuk mencari dan mengumpulkan fakta yang berkaitan dengan faktor-faktor yang mempengaruhi kelancaran pelaksanaan suatu kegiatan. Kegiatan pemeriksaan adalah salah satu bagian dari pengawasan. Pengawasan dapat di lakukan melalui laporan kerja yang di buat oleh pegawai maupun pemimpin yang langsung meninjau kelapangan untuk melihat apakah 
laporan sesuai dengan kondisi lapangan. Dalam hal ini berarti bahwa di dalam melakukan pemeriksaan dilihat apa saja yang akan di periksa yang berkaitan dengan Tenaga Kerja Asing tersebut.

Berdasarkan pada hasil penelitian menunjukan bahwa di dalam melakukan pemeriksaan pengawasan terhadap TKA di Solok Selatan sudah berjalan dengan baik dilihat dari kegiatan pemeriksaan yang dilakukan oleh petugas pengawas ke perusahaan tempat TKA tersebut bekerja yang diperiksa yaitu kelengkapan dokumen bekerja dari TKA baik itu IMTA maupun RPTKA serta pemeriksaan sudah berjalankah pengalihan ilmu dan keahlian dari TKA kepada TKI Pendamping yang dilakukan oleh petugas pengawas dari UPTD Pengawasan Ketenagakerjaan Wilayah III Provinsi Sumatera Barat.

Kemudian dari Imigrasi yang juga melakukan pengawasan terhadap TKA di Solok Selatan telah melakukan pemeriksaan yaitu paspor dan masa berlakunya paspor dari TKA, baru kemudian di periksa ada atau tidaknya memiliki Kitas untuk bekerja di perusahaan yang bersangkutan. Kemudian untuk PT Sumitomo Muaralabuh yang merupakan salah satu perusahaan di Solok Selatan yang menggunakan Tenaga Kerja Asing yang bisa dikatakan cukup banyak di tahun 2019 yaitu sekitar 13 orang TKA, tidak memiliki masalah dengan izin dan kelengkapan dokumen kerja yang mereka miliki dan untuk TKA yang bekerja di perusahaan ini tidak ada memiliki kendala dengan dokumen kerja dan izin mereka bekerja bila sewaktu-waktu diperiksa oleh petugas pengawas dari pemerintahan.

\section{Perbaikan}

Dalam tahap ini kegiatan yang dilakukan yaitu mencari jalan keluar untuk mengambil langkah-langkah tindakan koreksi terhadap penyimpangan-penyimpangan yang telah terjadi. Tindakan perbaikan ini berguna untuk mengetahui apakah pengawasan yang di lakukan sudah sesuai dengan standar yang telah di tetapkan dan hal ini dapat di lihat melalui ciri-ciri feedback atau umpan balik dari pengawasan yang di lakukan.

Dalam teknik ini akan dilihat jalan keluar atau solusi apa yang akan di ambil oleh petugas pengawas bila adanya permasalahan yang ditemukan di lapangan saat melakukan pengawasan terhadap TKA di Kabupaten Solok Selatan. Teknik perbaikan dari pengawasan terhadap TKA di Kabupaten Solok Selatan yang dilakukan oleh petugas pengawas baik itu dari UPTD Pengawasan Ketenagakerjaan Wilayah III Provinsi Sumatera Barat maupun Kantor Imigrasi Kelas I TPI Padang dalam menemukan solusi atau jalan keluar yang mereka ambil untuk kondisi di lapangan dapat dikatakan telah efektif karena petugas pengawas memecahkan permasalahan yang di temukan di lapangan dengan mencari solusi yang tepat dan sesuai dengan masalah yang dihadapi.

Pada teknik ini bila ada TKA yang bermasalah dengan izin nya baik yang ditemukan oleh Dinas Tenaga Kerja dan Transmigrasi Provinsi Sumatera Barat maupun oleh Kantor Imigrasi Kelas I TPI Padang, maka saat di lapangan itu juga akan diambil jalan keluar atau solusi apa yang terbaik yang mesti di ambil. Contoh permasalahan yang di hadapi oleh Imigrasi sebagai lembaga yang berwenang memberikan Visa bagi TKA yaitu penyalahgunaan Visa oleh TKA, Visa yang diberikan adalah untuk wisata atau kunjungan keluarga namun TKA tersebut malah bekerja di suatu daerah yang ada di Sumatera Barat maka dalam hal ini yang akan lebih berperan utama adalah Imigrasi karena menyangkut Visa atau izin tinggal yang diberikan bukan untuk izin bekerja. Maka jalan keluar yang diambil oleh Imigrasi adalah mendeportasi orang asing tersebut karena tujuannya untuk masuk ke suatu daerah tidak sesuai dengan izin yang diberikan dan menyalahi aturan. 


\section{Kendala yang dihadapi dalam melakukan Pengawasan terhadap TKA di Kabupaten Solok Selatan}

Kendala merupakan kekurangan atau keterbatasan yang di miliki oleh suatu organisasi. Kendala di sini berarti bahwa kekurangan atau keterbatasan yang di miliki oleh lembaga dan instansi terkait dalam melakukan pengawasan terhadap Tenaga Kerja Asing di Kabupaten Solok Selatan. Adapun kendala yang di hadapi oleh Dinas Tenaga Kerja dan Transmigrasi Provinsi Sumatera Barat dalam melakukan pengawasan terhadap TKA di Solok Selatan yaitu untuk kegiatan pengawasan berdasarkan laporan dari masyarakat itu anggarannya tidak ada sedangkan dana yang di anggarkan hanya untuk kegiatan pengawasan yang telah dijadwalkan dan belum adanya anggaran yang di khususkan untuk mengawasai TKA serta jarak yang jauh dan waktu yang di habiskan untuk pergi mengawasi TKA ke Solok Selatan.

Kendala yang juga di hadapi oleh UPTD Pengawasan Ketenagakerjaan Wilayah III Provinsi Sumatera Barat dalam melakukan pengawasan terhadap TKA di Solok Selatan yaitu jumlah petugas yang sedikit yang hanya berjumlah 6 orang, wilayah Solok Selatan yang jauh dan akses ke perusahaan yang sulit serta terbatasnya anggaran yang diberikan untuk kegiatan pengawasan ketenagakerjaan yaitu hanya kurang lebih 200 Juta satu tahun untuk mengawasi 800 perusahaan di UPTD Sijunjung. Kendala lainnya yaitu berhubungan dengan sarana dan prasarana yang digunakan oleh petugas pengawas untuk melakukan kegiatan pengawasan ketenagakerjaan yang mana sarana dan prasarana yang ada belum memadai yaitu mobil operasional yang digunakan untuk pergi ke lapangan baru hanya 1 (satu) yang ada, mengingat jarak, jumlah pengawas dan wilayah kab/kota yang berbeda dari setiap petugas pengawas tentu akan menyulitkan di dalam melakukan kegiatan pengawasan. Kemudian perlengkapan di kantor UPTD Wilayah III yang masih sangat minim yaitu hanya ada 1 buah komputer dan 2 buah laptop yang akan digunakan untuk membuat laporan kegiatan pengawasan ketenagakerjaan. Hal ini berarti bahwa banyak kekurangan yang ada di UPTD Pengawasan Ketenagakerjaan Wilayah III Provinsi Sumatera Barat dan membuat kegiatan pengawasan ketenagakerjaan kurang efektif untuk dilakukan.

Kemudian kendala yang dihadapi oleh Kantor Imigrasi Kelas I TPI Padang dalam melakukan pengawasan terhadap TKA di Solok Selatan yaitu alat transportasi yang masih kurang yaitu hanya ada satu mobil yang akan digunakan oleh personil intelijen untuk pergi ke lapangan dan mobil operasional yang ada tidak cocok untuk area medan jalan di Solok Selatan. Kemudian safety (alat pelindung) yang belum dimiliki oleh personil intelijen untuk keadaan darurat di lapangan seperti senjata api dan lokasi Solok Selatan yang jauh serta alat komunikasi dan jaringan yang susah akan menyulitkan personil intelijen untuk melaporkan kegiatan pengawasan di lapangan. Kendala lainnya yaitu anggaran yang diberikan untuk kegiatan intelijen keimigrasian masih sangat minim dan jumlah personil intelijen yang hanya berjumlah 3 orang. Hal ini berarti bahwa banyak kendala yang masih harus di hadapi oleh intelijen keimigrasian dalam mengawasi TKA di Kabupaten Solok Selatan.

Dari kendala-kendala yang di hadapi oleh Dinas Tenaga Kerja dan Transmigrasi Provinsi Sumatera Barat, UPTD Pengawasan Ketenagakerjaan Wilayah III Provinsi Sumatera Barat dan Kantor Imigrasi Kelas 1 TPI Padang dalam melakukan pengawasan terhadap TKA di Solok Selatan tentunya akan mengakibatkan tidak efektifnya pelaksaan pengawasan yang akan di lakukan mengingat pengawasan tersebut yang mesti untuk segera di lakukan namun karena terhalang oleh kekurangan yang ada 
membuat pengawasan terebut sedikit mengalami gangguan.

\section{Upaya yang dilakukan untuk meningkatkan efektivitas pengawasan terhadap Tenaga Kerja Asing (TKA) di Kabupaten Solok Selatan}

Upaya merupakan suatu usaha yang dilakukan oleh suatu instansi untuk meningkatkan kinerja organisasinya. Dalam penelitian ini, penulis melihat upaya yang di lakukan oleh lembaga dan instansi terkait yang melakukan pengawasan terhadap Tenaga Kerja Asing di Kabupaten Solok Selatan dalam mengatasi kendala yang mereka hadapi dalam melakukan pengawasan dan upaya yang dilakukan untuk meningkatkan efektivitas pengawasan terhadap TKA di Kabupaten Solok Selatan.

Dalam melakukan pengawasan terhadap Tenaga Kerja Asing di Kabupaten Solok Selatan Dinas Tenaga Kerja dan Transmigrasi Provinsi Sumatera Barat, UPTD Pengawasan Ketenagakerjaan Wilayah III Provinsi Sumatera Barat dan Kantor Imigrasi Kelas 1 TPI Padang masih terkendala dengan keterbatasan sumber daya yang dimiliki baik jumlah petugas pengawas, anggaran yang diberikan tidak memadai dan masih kurangnya sarana dan prasarana yang dibutuhkan. Untuk mengatasi kekurangan sumber daya manusia dan anggaran yang tidak mencukupi lembaga dan instansi terkait tersebut selalu berupaya untuk mengusulkan ke pusat agar adanya penambahan personil atau petugas pengawas, permohonan penambahan anggaran serta permintaan di lakukannya pengadaan sarana dan prasarana terutama alat transportasi yang akan di gunakan oleh petugas pengawas untuk melakukan pengawasan ke lapangan. Kemudian untuk situasi yang di hadapi di lapangan lembaga dan instansi terkait selalu berupaya untuk melakukan kerjasama yang baik agar bisa saling membantu dan besinergi bila ada permasalahan yang ditemukan di lapangan yang berkaitan dengan TKA ini, hal ini dilakukan agar tidak ada satu pun TKA yang bekerja di Solok Selatan yang luput dari pengawasan.

\section{PENUTUP}

Berdasarkan hasil penelitian yang telah dilakukan, maka penulis dapat menarik kesimpulan bahwa pelaksanaan pengawasan Tenaga Kerja Asing (TKA) oleh Pemerintah Pusat dan Daerah di Kabupaten Solok Selatan telah berjalan cukup baik namun belum begitu optimal karena masih adanya kendala-kendala yang di hadapi dalam pelaksanaanya. Hasil penelitian menunjukan bahwa lembaga dan instansi terkait yang melakukan pengawasan ini seperti Dinas Tenaga Kerja dan Transmigrasi Provinsi Sumatera Barat, UPTD Pengawasan Ketenagakerjaan Wilayah III Provinsi Sumatera Barat dan Kantor Imigrasi Kelas I TPI Padang telah melakukan pengawasan dengan baik dilihat dari teknik pengawasan yang dilakukan yaitu ada pemantaun telah dilakukan dengan baik yaitu memantau TKA tersebut langsung ke tempat ia bekerja di perusahaan yang ada di Solok Selatan. Kemudian pemeriksaan telah dilakukan dengan baik pula oleh lembaga dan instasi terkait seperti memeriksa dokumen kerja, IMTA, RPTKA, pembayaran pajak dan masa berlakunya paspor. Hal ini dilakukan agar tidak ada TKA yang melakukan kecurangan bila izinnya telah habis. Selanjutnya yaitu perbaikan ini adalah teknik untuk permasalahan yang ditemui dilapangan dan solusi apa yang akan diambil oleh petugas pengawas, teknik ini pun juga telah dilakukan dengan baik berkaitan masalah yang ditemukan dilapangan.

Masih terbatasnya jumlah sumber daya manusia yang dimiliki merupakan salah satu faktor yang menyebabkan masih kurang optimalnya pengawasan yang dilakukan oleh lembaga dan instansi terkait dalam melakukan pengawasan terhadap TKA karena jumlah yang ada sekarang belum sebanding dengan luasnya wilayah 
dan jarak tempuh yang jauh yang mesti di lewati oleh petugas pengawas serta di tambah dengan sangat minimnya sarana dan prasarana yang di butuhkan oleh petugas pengawas untuk melakukan pengawasan ke lapangan terutama kendaraan operasional yang akan di gunakan yaitu mobil. Hal ini perlu untuk mendapatakan perhatian lebih dari pemerintahan pusat untuk melakuakn penambahan jumlah pegawai petugas pengawas dan melakukan pengadaan sarana dan prasarana yang memadai sehingga memudahkan lembaga dan instansi terkait untuk melakukan pengawasan terhadap Tenaga Kerja Asing ini.

\section{DAFTAR KEPUSTAKAAN}

Antaranews, S. (2018). Tanpa Paspor dan diduga Menyalahgunakan Visa Warga China diamankan di Solok Selatan. Diakses Pada Tanggal 7 Februari 2019.

Fahmi, I. (2016). Manajemen Sumber Daya Manusia Teori dan Aplikasinya. Bandung: Alfabeta.

Handoko, H. (2000). Manajemen Edisi Pertama. Yogyakarta: BPFE.

Islamiah, R. Q. A., Noak, P. A., \& Winaya, I. K. (2015). Efektivitas Pengawasan Dinas Sosial dan Tenaga Kerja Terhadap Penggunaan Tenaga Kerja Asing Berdasarkan Peraturan Menteri Ketenagakerjaan Nomor 16 Tahun 2015 di Kabupaten Badung. 1-7. Retrieved from https://www.neliti.com/id/publications /165187/efektivitas-pengawasandinas-sosial-dan-tenaga-kerjaterhadap-penggunaan-tenaga.

Peraturan Gubernur Provinsi Sumatera Barat Nomor 14 Tahun 2015 tentang Petunjuk Pelaksanaan Retribusi Perpanjangan Izin Mempekerjakan Tenaga Kerja Asing. (2015).
Peraturan Menteri Ketenagakerjaan Nomor 10 Tahun 2018 tentang Tata Cara Penggunaan Tenaga Kerja Asing. (n.d.).

Siagian, S. (2011). Manajemen Stratejik. Jakarta: Bumi Aksara.

Sugiyono. (2017). Metode Penelitian Kuantitatif, Kualitatif dan $R \& D$. Bandung: Alfabeta.

Sule, E. T. dan K. S. (2012). Pengantar Manajemen. Jakarta: Kencana.

Sumbar, A. (2016). Solok Selatan Panggil Perusahaan Pembawa TKA Ilegal. Diakses Pada Tanggal 7 Februari 2019.

Suryandono, W. (2017). Tenaga Kerja Asing Analisis Politik Hukum. Jakarta: Yayasan Pustaka Obor Indonesia.

Terry, G. R. dan L. W. R. (2012). DasarDasar Manajemen (Penerjemah G.A Ticoalu). Jakarta: Bumi Aksara.

Undang-Undang Nomor 13 Tahun 2003 Tentang Ketenagakerjaan. (n.d.). 